\title{
Variants of uncertain clinical significance in hereditary breast and ovarian cancer genes: best practices in functional analysis for clinical annotation
}

For numbered affiliations see end of article.

Correspondence to Dr Alvaro N Monteiro, Cancer Epidemiology, H. Lee Moffitt Cancer Center and Research Institute, Tampa, FL 33612, USA Alvaro.Monteiro@Moffitt. org and Dr Maaike P G Vreeswijk, Human Genetics, Leiden University Medical Center, Leiden, 2300RC, The Netherlands:

M.P.G.Vreeswijk@lumc.nl

Received 12 June 2019 Revised 28 October 2019 Accepted 1 December 2019

Check for updates

(c) Author(s) (or their employer(s)) 2020. No commercial re-use. See rights and permissions. Published by BMJ.

To cite: Monteiro AN, Bouwman P, Kousholt AN, et al. J Med Genet Epub ahead of print: [please include Day Month Year]. doi:10.1136/

jmedgenet-2019-106368

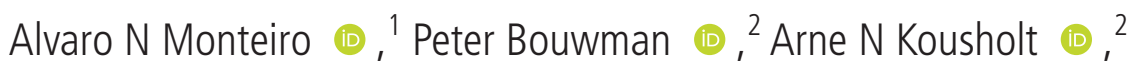

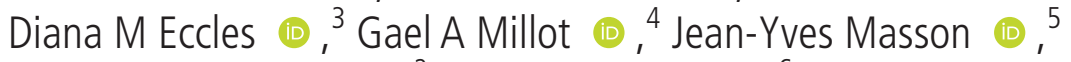
Marjanka K Schmidt @ (1), ${ }^{2}$ Shyam K Sharan (1), ${ }^{6}$ Ralph Scully (1) , Lisa Wiesmüller (1) , ${ }^{8}$ Fergus Couch (1) , ${ }^{9}$ Maaike P G Vreeswijk (1) ${ }^{10}$

\section{INTRODUCTION}

Since the identification and cloning of BRCA1 in $1994,{ }^{1}$ and shortly thereafter of $B R C A 2,{ }^{2}$ genetic tests of germline DNA to identify pathogenic variants in genes linked to hereditary breast and ovarian cancer (HBOC) have become mainstream. ${ }^{3}$ These tests are critical to identify women at increased risk relative to the general population. Women at moderate risk $(2 \leq$ relative risk $(\mathrm{RR})<4)$ may benefit from enhanced screening and chemoprevention while those at high risk $(\mathrm{RR} \geq 4)$, including those with $B R C A 1$ and $B R C A 2$ pathogenic variants, may also benefit from preventive surgery. Germline mutation testing is also becoming increasingly relevant in the cancer treatment setting because carriers of pathogenic variants in BRCA1/2 may benefit from poly-ADP ribose polymerase (PARP) inhibitors. ${ }^{45}$ Importantly, genetic tests can identify individuals in HBOC families who do not carry the relevant predisposing allele and are not at elevated risk of cancer. ${ }^{6}$

A significant fraction of documented variants in BRCA1 and BRCA2 are considered variants of uncertain clinical significance (VUS), for which cancer association has not been assessed or could not be determined due to insufficient information (table 1). In ClinVar (https://www.ncbi.nlm.nih.gov/ clinvar/), a clinically oriented database, currently $\sim 37 \%$ of $B R C A 1$ and $\sim 45 \%$ of $B R C A 2$ unique variants recorded are VUS. Thus, there is a critical need to classify variants according to their pathogenicity.

Over the past decade, functional assays have emerged that can be included as a source of evidence to classify variants according to their pathogenicity, with the potential to greatly accelerate classification. ${ }^{7}$ Here, we discuss several technical and conceptual aspects relevant for the use of functional assays in the classification of variants. We present best practice recommendations to improve annotation quality and accuracy, and to provide a basis for the comparison and integration of functional data from different laboratories (box 1). For the coming years, we anticipate that recent technological developments such as VAMP-Seq (variant abundance by massively parallel sequencing) or high-throughput Clustered Regularly Interspaced
Short Palindromic Repeats (CRISPR)-based saturation mutagenesis will enable the functional assessment of every missense variant for all moderate-risk and high-risk HBOC genes. ${ }^{8-10}$ Once established and validated, these catalogues of functional data will provide valuable information for clinical annotation. The recommendations proposed here are the result of a discussion that started at a Netherlands Cancer Institute workshop on Functional Analysis of Sequence Variants in Hereditary Breast and Ovarian Cancer Genes (Amsterdam, The Netherlands) and was followed by additional discussion and extensive refinement. It represents a consensus view that was self-developed by an international group of investigators (the authors) who have been active in this field.

\section{ASSESSMENT OF THE EVIDENCE FOR ASSOCIATION OF EACH GENE WITH HBOC RISK}

The first step in developing or interpreting results from functional assays is to understand the level of evidence that links a particular gene to breast and ovarian cancer risk. ${ }^{3}$ To date, there are nine genes for which an association between protein-truncating variants and breast cancer risk has been established (ATM, BRCA1, BRCA2, CDH1, CHEK2, PALB2, PTEN, STK11 and TP53) and several more (BARD1, FANCM, NBN, NF1, MLH1, MSH2, MSH6, PMS2, RAD51C and RAD51D) ${ }^{311-13}$ for which association has been suggested but not yet firmly established. At least 12 genes have been implicated in ovarian cancer risk (ATM, BRCA1, BRCA2, BRIP1, MLH1, MSH2, MSH6, PALB2, PMS2, RAD51C and RAD51D). ${ }^{14} 15$

Development of functional tests for emerging genes provides opportunities to uncover new mechanistic aspects of their biology and identify functional domains. However, developers of functional assays should consider that clinical recommendations are unlikely to be made based on variants in genes for which the association has not been robustly established. Thus, a detailed understanding of the strength of evidence for association between each gene (and its variant alleles) and HBOC risk should be sought to evaluate the clinical utility of a proposed functional assay. 
Table 1 Fraction of VUS in BRCA1 and BRCA2

\begin{tabular}{|c|c|c|c|c|c|c|c|c|}
\hline \multirow[b]{2}{*}{ Databases } & \multicolumn{2}{|l|}{$\mathrm{BIC}^{*}$} & \multicolumn{2}{|c|}{ ClinVart } & \multicolumn{2}{|c|}{ BRCA Exchange‡ } & \multicolumn{2}{|c|}{ gnomAD§ } \\
\hline & $N$ & $\%$ (\%VUS) & $N$ & $\%$ (\%VUS) & $N$ & $\%$ (\%VUS) & $N$ & $\%$ \\
\hline$B R C A 1$ unique variants & 1781 & 100 & 5821 & 100 & 7898 & 100 & 2936 & 100 \\
\hline BRCA1 VUS & 891 & $50.0(100)$ & 2146 & $36.9(100)$ & 5186 & $65.7(100)$ & n/a & $\mathrm{n} / \mathrm{a}$ \\
\hline BRCA1 missense & 607 & $34.1(68.1)$ & 1715 & $29.5(79.9)$ & 1892 & $24.0(36.5)$ & 938 & 31.9 \\
\hline BRCA1 missense VUS & 569 & $31.9(63.9)$ & 1633 & $28.1(76.1)$ & 1714 & $21.7(33.1)$ & $\mathrm{n} / \mathrm{a}$ & $\mathrm{n} / \mathrm{a}$ \\
\hline$B R C A 2$ unique variants & 2000 & 100 & 8119 & 100 & 10422 & 100 & 4262 & 100 \\
\hline$B R C A 2$ VUS & 1065 & $53.3(100)$ & 3615 & $44.5(100)$ & 6980 & $67.0(100)$ & $\mathrm{n} / \mathrm{a}$ & $\mathrm{n} / \mathrm{a}$ \\
\hline$B R C A 2$ missense & 891 & $44.6(83.7)$ & 3111 & $38.3(86.1)$ & 3484 & $33.4(49.9)$ & 1909 & 44.8 \\
\hline BRCA2 missense VUS & 838 & $41.9(78.7)$ & 3011 & $37.1(83.3)$ & 3190 & $30.6(45.7)$ & $\mathrm{n} / \mathrm{a}$ & $\mathrm{n} / \mathrm{a}$ \\
\hline
\end{tabular}

${ }^{*} \mathrm{BIC}$ (https://research.nhgri.nih.gov/bic/) is a locus-specific database established in 1995 for BRCA1 and BRCA2 variants, including loci primarily found in clinical or research testing.

tClinVar (https://www.ncbi.nlm.nih.gov/clinvar/) is a public archive of reports of the relationships among human variations and phenotypes and includes submissions reporting variants found in patient samples from clinical or research testing, and from the literature (note: ClinVar also includes BIC data) ${ }^{69}$ VUS counts also include conflicting assessments.

¥BRCA Exchange (http://brcaexchange.org/) pools data on BRCA1/2 genetic variants and corresponding clinical data from around the world (including BIC, ClinVar, 1000 Genomes Project). BRCA Exchange is part of the Global Alliance for Genomics and Health. VUS counts also include 'not yet reviewed'.

$\S g n o m A D$ (http://gnomad.broadinstitute.org/), initially released as ExAC aggregates and harmonises both exome and genome sequencing data from a wide variety of large-scale sequencing projects. It does not contain pathogenicity assessments. All searches were conducted in December 2017.

BIC, Breast Cancer Information Core; gnomAD, The Genome Aggregation Database; VUS, variants of uncertain clinical significance.

An additional aspect to consider when developing a functional assay is the proportion of missense VUS that are probably pathogenic. Missense variation is unlikely to significantly affect the overall protein function when located in disordered regions or

Box 1 Summary recommendations for the development, reporting and interpretation of functional assays

- Assess the strength of evidence for association between each gene and hereditary breast and ovarian cancer risk to evaluate the potential clinical utility of a proposed functional assay.

- Consider the assumptions, biological characteristics, controls and limitations of each assay.

- Choose genomic DNA/cDNA/protein sequences that correspond to the coding sequence of the most commonly found haplotype in non-affected individuals to be used as a reference (wild-type).

- A minimal set of non-pathogenic and pathogenic variants should be used as internal reference for each run of an assay. Larger sets of reference variants should be used to assess the overall sensitivity and specificity of an assay.

- Verify that elements of the assay (reagents and data) have been through quality control, including periodical verification of cell line and strain identity (eg, identity by short tandem repeat analysis for mammalian cells and phenotyping for yeast strains) and quality (mycoplasma testing).

- Due to protein stability issues, exercise caution when developing and interpreting results from model organisms that are cultured at temperatures lower than $37^{\circ} \mathrm{C}$.

- Inspect data to identify and correct batch effects.

- Do not assume that intermediate levels of activity necessarily reflects intermediate risks.

- In addition to loss-of-function effects also consider dominant negative and gain-of-function effects.

- When reporting results use explicitly defined terminology and aim for the development of a controlled vocabulary.

- Be explicit about assay's limitations, performance metrics and thresholds used to classify variants. in repeat motifs. Therefore, functional assays for these regions (or for a protein with a large portion of its coding sequence composed by these regions) may not be a priority.

\section{ASSESSMENT OF VARIANT PATHOGENICITY}

Genes implicated in HBOC are tumour suppressor genes and therefore variants leading to disruption of function(s) are usually considered pathogenic for clinical purposes. Notable exceptions of variants with dominant negative or gain-of-function have also been reported. ${ }^{16}$ Loss-of-function genetic alterations include frameshift and nonsense variants leading to truncation of a functionally important segment of the protein, alterations of donor and acceptor splice sites and large genomic rearrangements altering segments of the coding region. Conversely, synonymous changes without effect on mRNA splicing are considered non-pathogenic. These variants can be reliably classified by a rule-based system that incorporates general DNA/RNA/protein rules and takes into account exceptions specific to each gene (ENIGMA rules for classification of BRCA1 and BRCA2 variants: https://enigmaconsortium.org/library/general-documents/ enigma-classification-criteria/).

For a significant fraction of rare variants pathogenicity cannot be predicted based on DNA changes alone. Primarily, these variants include small deletions or insertions that do not disturb the reading frame, missense changes, intronic and exonic variants that may lead to altered mRNA splicing and in-frame exon deletions or duplications. Missense variants represent the largest contributor to this class, making up to $79.9 \%$ and $86.1 \%$ of all $B R C A 1$ and BRCA2 VUS in ClinVar, respectively (table 1).

Classification of these BRCA1/2 variants for clinical use can be based on the American College of Medical Genetics and Genomics/Association for Molecular Pathology (ACMG/AMP)) guidelines in which pathogenicity is determined by the entire body of evidence. ${ }^{7}$ In this proposed five-tier classification, variants with $>90 \%$ certainty of being pathogenic (which includes likely pathogenic and pathogenic variants), are considered actionable, and carriers are managed as high risk $(\mathrm{RR} \geq 4)$. Evidence is qualitatively weighed as strong, moderate, supporting or not used. Functional data provide strong (PS3: well-established functional studies show a deleterious effect) and moderate (PM1: 


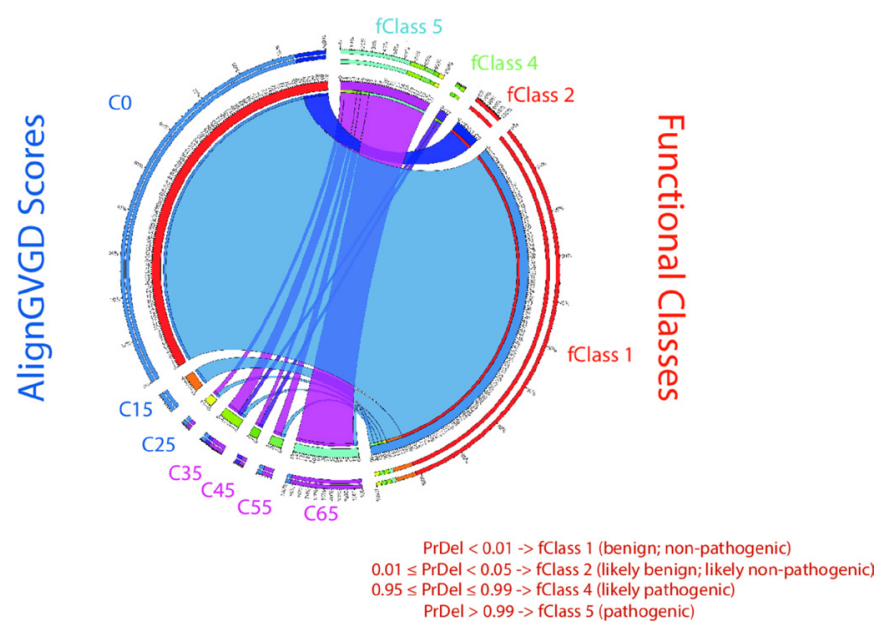

Figure 1 Circos plot illustrating the concordance between alignGVGD predictions and experimental data derived from analysis of BRCA1 Cterminal variants (aa 1396-1863). Variants were analysed using the transcription activation assay ${ }^{29}$ and assigned to functional classes by VarCall. ${ }^{57}$ Blue ribbons show that all variants scoring $\mathrm{C} 0$ and $\mathrm{C} 15$ in alignGVGD and predicted to have no or little functional impact score as non-pathogenic or likely non-pathogenic (fClass 1 or 2) in a validated functional assay. Conversely, most variants scoring as C65 and predicted to have a functional score as fClass5 (thick purple ribbon). Despite the strong concordance between alignGVGD and the transcriptional assay, a small but significant fraction of variants scoring as fClass 1 were incorrectly predicted (C45-C65).

mutational hot spot or well-studied functional domain without benign variation) evidence for pathogenicity; and strong (BS3: well-established functional studies show no deleterious effect) evidence for benign impact. ${ }^{7}$ Reproducible and robust functional assays that have been validated are considered the most wellestablished source.

Alternatively, classification of BRCA1/2 variants can be based on a multifactorial statistical model that incorporates data on family history, co-segregation and co-occurrence with another allele with a known pathogenic variant in the same gene (because biallelic inactivation is embryonic lethal while biallelic partial loss of function leads to Fanconi anaemia). ${ }^{17}$ In the International Agency for Research on Cancer (IARC) proposed five-tier classification, variants with $>95 \%$ certainty of being pathogenic are considered actionable. ${ }^{18}$ Variants that reach $>1.0 \%$ allele frequency in the population are considered unlikely to be pathogenic on their own but there is simply insufficient clinic and family-based genetic information to determine the likelihood of pathogenicity of many uncommon $(<1.0 \%)$ variants. Currently, functional data are not integrated in these multifactorial statistical models.

The effects of these rare VUS can be predicted by a wide variety of publicly available in silico tools with variable performance. ${ }^{19}{ }^{20}$ For tools that use multiple sequence alignments, performance has been tied to the choice of alignments and calibration. ${ }^{21-23}$ Reliance on multiple sequence alignment and evolutionary approaches may also generate false negatives. For example, Kondrashov et al have estimated that approximately $10 \%$ of variants that are classified as 'tolerated', because a corresponding amino acid residue is found in the cognate position in another species, only score as 'tolerated' because of compensatory variation elsewhere in the protein sequence. ${ }^{24}$ Despite these limitations, algorithms are constantly improving and the concordance between some predictors and empirical data is sufficiently high (figure 1) to guide prioritisation of variants for functional assessment. However, empirical functional data will be necessary for the robust clinical annotation of uncommon variants.

\section{THE SPECTRUM OF LOW-RISK, MODERATE-RISK AND HIGH- RISK ALLELES IN HBOC GENES}

When developing or interpreting a functional assay for VUS classification, the level of risk conferred by pathogenic variants should be considered. Findings of pathogenic variants in a low penetrance gene $(R R<2)$ currently do not trigger clinical recommendations making the development of a functional assay a low priority. It is also plausible that variants within the same gene may span the spectrum of low $(R R<2)$, moderate $(2 \leq R R$ $<4)$ and high $(R R \geq 4)$ risk. In other words, distinct 'pathogenic' variants in the same gene may carry significantly different levels of risk.

Currently, the multifactorial statistical model for classification of $B R C A 1$ or $B R C A 2$ variants determines whether a variant is likely to be pathogenic. The clinical inference of the IARC classification is based on variants that typically are associated with a high cancer risk comparable to a truncating variant in BRCA1 or $B R C A 2(\mathrm{RR} \geq 4) .{ }^{18}$ However, it is now clear that some pathogenic missense variants in BRCA1 (p.R1699Q and p.V1736A) and BRCA2 (p.Y3035S and p.G2508S) confer only moderate breast cancer risk $(2 \leq \mathrm{RR}<4) .{ }^{25-27}$ On the other hand, the BRCA2 p.K3326X, classified by the model as non-pathogenic, was shown to confer a mildly increased risk $(R R=1.4)$ of breast and ovarian cancer. ${ }^{28}$ Although finding this variant would not trigger a change in clinical recommendation currently, this variant can contribute to polygenic risk scores based on common genetic variants that are now being used for risk stratification, and may prove effective for selection of screening and prevention options.

Some assays may have the ability to reflect different levels of risk depending on the dynamic range of the read-out and on the specific biological assay being performed. It is important to stress that it should not be assumed that intermediate levels of activity in a biochemical or biological assay necessarily reflects intermediate risks. Several reference variants with known intermediate risks should be used to determine the ability of an assay to reflect the continuum of risk. While the transcription activation assay for BRCA1 does not seem to discriminate between variants with intermediate risks from variants associated with high risk, ${ }^{29}$ the $B R C A 2$ homologous recombination (HR) assay may be able to distinguish high from moderate and low/neutral as suggested by functional assessment of variant p.Y3035s. ${ }^{30}$ For genes in which pathogenic variants are clearly associated with disease risk, a two-stage reporting system has been proposed, that is, the first stage would establish pathogenicity of the variant based on multiple criteria and the second stage would denote the likely severity or clinical consequence for that variant (high, moderate or low risk). ${ }^{31}$ Capturing the full spectrum of risk associated with distinct pathogenic variants is a critical challenge for assay development and for reporting laboratories.

Classification from both ACMG/AMP and multifactorial models are designed to distinguish high-risk variants (RR $\geq 4$; actionable) from not high-risk $(\mathrm{RR}<4)$ variants and are currently not suitable to identify moderate-risk variants. From a clinical standpoint, while these models have a binary outcome (actionable vs non-actionable), carriers of moderate-risk variants $(2 \leq \mathrm{RR}<4)$ may also benefit from enhanced screening. ${ }^{32}$ 


\section{FUNCTIONAL ASSAYS FOR HBOC GENE VARIANT CLASSIFICATION}

For the purposes of our discussion, 'function' is considered as any aspect defined by the Gene Ontology Consortium ${ }^{33}$ molecular function, cellular component and biological processes. A 'functional assay' is generally defined as any in vitro and in vivo system able to determine the impact of a variant by assessing its effect on protein stability, conformation and function. Thus, assays for splicing alterations are not considered functional assays for the purposes of this manuscript (for assessment of splice variants please refer to Thomassen et al and Walker et $a l^{3435}$ ).

Several characterised functions of the BRCA1 and BRCA2 proteins have been exploited in the development of functional assays. ${ }^{36-38}$ Reflecting their central role in DNA damage repair, many assays revolve around measuring the ability of the variant to promote survival following DNA insults, such as treatment with ionising radiation or DNA damaging compounds. In addition to these viability assays, specific biochemical assays such as those measuring HR or ubiquitylation are also rooted in the known biology of BRCA1 and BRCA2. Finally, more limited biochemical assays, measuring binding to specific interacting proteins have also been applied to the functional analysis of variants. $^{36-38}$

In general, there is enough evidence to tie each of these functions to the aetiology of tumours arising in carriers. However, their individual contribution to cancer risk is unclear, making it difficult to determine which assay is more or less biologically appropriate, or to assign different weights to results obtained from different assays. Rather, the determination of which assays should be used for clinical annotation relies on their accuracy, and not on their biological properties. Preliminary analysis has shown that these functional assays display high $(>80 \%)$ sensitivity and specificity (table 2). ${ }^{39}$

After the development of a large number of functional assays for high-risk genes (BRCA1, BRCA2 and TP53), 363740 significant attention has been focused on developing assays for other highrisk/moderate-risk genes such as PALB2, ATM and CHEK2. ${ }^{4-46}$ However, here we will focus on functional assays for missense variants of $B R C A 1$ and $B R C A 2$ as exemplars from which we have derived general guidelines.

Functional assays can be defined by three broad categories according to their experimental set-up (cell-free or cell-based), host (human or model organism) and read-out. Result interpretation requires careful consideration of the assumptions, the biological characteristics and limitations of each assay.

Cell-free systems either test a specific biochemical activity in vitro (eg, phosphopeptide binding, ubiquitin ligase activity, DNA combing, DNA binding, DNA recombination), protein-protein interactions (eg, yeast two-hybrid screening, co-immunoprecipitations) or the effect of different factors on protein structure and stability (eg, protease sensitivity, calorimetry). Interpretation of results from cell-free assays should consider that they are restricted to specific functions, sometimes limited to specific regions of the protein, and may be particularly sensitive to temperature, buffer conditions and concentrations of exogenous substrates.

Cell-based systems use a human or model organism (eg, yeast, bacteria or mouse) host cell as the basis for the assay. Cell-based systems can be further distinguished as in cellulo (when the assay context is a single cell) or in vivo (in the context of a whole metazoan organism), although there are currently no established in vivo functional assays for VUS. We recommend periodical authentication of cell line and strain identity by short tandem repeat analysis and phenotyping, respectively. Cell lines should be checked regularly for mycoplasma infection. Interpretation of results from assays performed in model systems should consider the degree of divergence of proteins from the host involved in the assay, differences in biology and in growth conditions.

Cell-based assays can be further defined by read-out. Reporter systems include those in which the read-out for functional impact is an ectopic reporter (eg, transcription activation or HR assays) or in which ectopic overexpression in a heterologous system leads to a defined phenotype (eg, small colony phenotype in yeast). Limitations of reporter systems based on ectopic expression may include artefacts of over expression. Alternatively, assays in which the full length variant allele/protein replaces the endogenous gene/protein and defined biological processes are assessed are considered complementation/perturbation assays. Some assays may combine reporter systems and complementation.

Ultimately, the value of an assay will depend on its performance, defined using a set of known non-pathogenic and pathogenic control variants as reference (see below). Given the complexity of the interaction of multiple biochemical functions and breast and ovarian cancer phenotype, it is uncertain that there will be a single comprehensive and highly accurate functional assay. Rather, the combination of approaches using diverse sources of data obtained with transparent methodology and careful interpretation is likely to solve the challenges of VUS in HBOC genes.

Mouse models, although not suitable for high throughput analysis, can be helpful in determining the effect of such variants on tumour predisposition and treatment response. Brca1 mutant mice expressing the p.I26A variant showed that the E3 ubiquitin ligase activity of BRCA1 is dispensable for tumour suppression and mice expressing 185delAG (c.68_69delAG; p.E23VfsTer17) revealed the hypomorphic nature of this pathogenic variant in response to therapy. ${ }^{47-49}$ A knock-in mouse model of the BRCA2 p.G25R variant, which had no effect on ES cell viability but had subtle defect in HR, showed a significant increase in tumour formation in mutant animals. ${ }^{50}$ Similarly, the effect on tumour predisposition of an alternatively spliced Brca 2 transcript lacking exons 4-7 was revealed in mutant mice lacking these exons. ${ }^{51}$

\section{REQUIREMENTS FOR A CLINICALLY RELEVANT FUNCTIONAL ASSAY}

The analytical validity is the degree of accuracy with which a functional assay correctly classifies variants as pathogenic or nonpathogenic. For each assay performance metrics (true positive rate or sensitivity; true negative rate or specificity; false positive and false negative rates; positive and negative likelihood ratios; false discovery rate; false omission rate; positive predicted value or precision; negative predictive value; accuracy and diagnostic OR) should be derived from testing a panel of known pathogenic and non-pathogenic variants. The recommendation is to chose a set of pathogenic and non-pathogenic missense controls whose likelihood of pathogenicity has been established by the multifactorial statistical model and can be found in a recent ENIGMA publication. $^{363752}$

There are no specific recommendations about which threshold of sensitivity or specificity should be used to consider the inclusion of data from a functional assay for variant classification. Plon et $a l^{18}$ have pointed out that clinical decisions based on predictive values of $80 \%-85 \%$ are normally used in oncology. A more strict approach would require that the lower bound of the 95\% CI be above the suggested 80\%-85\% threshold but that 
Table 2 Categories and performance of functional assays for BRCA1 and BRCA2

\begin{tabular}{|c|c|c|c|c|c|c|c|}
\hline Gene & Assay & Set-up & Read-out & $\begin{array}{l}\text { \# of variants assessed } \\
\text { (\# of known non- } \\
\text { pathogenic; pathogenic)* }\end{array}$ & $\begin{array}{l}\text { Sensitivity } \\
(95 \% \mathrm{Cl}) \dagger\end{array}$ & $\begin{array}{l}\text { Specificity } \\
(95 \% \mathrm{Cl}) \dagger\end{array}$ & Reference \\
\hline BRCA1 & Colony size & Cell-based (yeast) & Complementation/perturbation & $40(15 ; 25)$ & $\begin{array}{l}0.96 \\
(0.80 \text { to } 1.00)\end{array}$ & $\begin{array}{l}0.93 \\
\text { (0.68 to } 1.00)\end{array}$ & 58 \\
\hline$B R C A 1$ & Yeast localisation & Cell-based (yeast) & Complementation/perturbation & $40(15 ; 25)$ & $\begin{array}{l}0.84 \\
(0.64 \text { to } 0.95)\end{array}$ & $\begin{array}{l}0.93 \\
(0.68 \text { to } 1.00)\end{array}$ & 58 \\
\hline$B R C A 1$ & Transcription activation & Cell-based (HEK293T) & Reporter system & $204(25 ; 40)$ & $\begin{array}{l}1.00 \\
(0.75 \text { to } 1.00)\end{array}$ & $\begin{array}{l}1.00 \\
\text { (0.83 to } 1.00)\end{array}$ & 29 \\
\hline BRCA1 & UbcH5a binding & Cell-based (yeast) & Reporter system & 35 & n/a & $\mathrm{n} / \mathrm{a}$ & 70 \\
\hline$B R C A 1$ & Uniquitin ligase activity & Cell-free (in vitro) & In vitro enzymatic activity & 35 & $\mathrm{n} / \mathrm{a}$ & $\mathrm{n} / \mathrm{a}$ & 70 \\
\hline$B R C A 1$ & Protease sensitivity & Cell-free (in vitro) & In vitro binding activity & $117(10 ; 14)$ & $\begin{array}{l}0.79 \\
(0.49 \text { to } 1.00)\end{array}$ & $\begin{array}{l}0.80 \\
(0.44 \text { to } 0.98)\end{array}$ & 56 \\
\hline$B R C A 1$ & $\begin{array}{l}\text { Phosphopeptide } \\
\text { binding activity }\end{array}$ & Cell-free (in vitro) & In vitro binding activity & $117(10 ; 14)$ & $\begin{array}{l}0.86 \\
\text { (0.57 to } 0.98)\end{array}$ & $\begin{array}{l}1.00 \\
\text { (0.69 to } 1.00)\end{array}$ & 56 \\
\hline BRCA1 & Cisplatin sensitivity & $\begin{array}{l}\text { Cell-based (mouse ES } \\
\text { cells) }\end{array}$ & Complementation/perturbation & $86(25 ; 9)$ & $\begin{array}{l}1.00 \\
(0.63 \text { to } 1.00)\end{array}$ & $\begin{array}{l}1.00 \\
(0.83 \text { to } 1.00)\end{array}$ & 62 \\
\hline$B R C A 1$ & BARD1 binding & Cell-based (yeast) & Reporter system & $1287(3 ; 19)$ & $\mathrm{n} / \mathrm{a}$ & $\mathrm{n} / \mathrm{a}$ & 71 \\
\hline$B R C A 1$ & Uniquitin ligase activity & Cell-free (in vitro) & In vitro enzymatic activity & $1287(3 ; 19)$ & $\mathrm{n} / \mathrm{a}$ & $\mathrm{n} / \mathrm{a}$ & 71 \\
\hline$B R C A 1$ & Haploid cell survival & Cell-based (HAP1 cells) & Complementation/perturbation & $3893(22 ; 162) \S$ & 0.967 & 0.982 & 10 \\
\hline BRCA1 & $\begin{array}{l}\text { Homologous } \\
\text { recombination }\end{array}$ & $\begin{array}{l}\text { Cell-based } \\
\text { (RG37-shBRCA1 cells) }\end{array}$ & Complementation/perturbation & $78(6 ; 7)$ & 1.00 & 1.00 & 72 \\
\hline$B R C A 1$ & Localisation & $\begin{array}{l}\text { Cell-based } \\
\text { (RG37-shBRCA1 cells) }\end{array}$ & Complementation/perturbation & $78(6 ; 7)$ & 0.714 & 1.00 & 72 \\
\hline$B R C A 1$ & $\begin{array}{l}\text { Protein expression and } \\
\text { stability }\end{array}$ & Cell-free (in vitro) & $\begin{array}{l}\text { In vitro solubility and } \\
\text { thermostability }\end{array}$ & $78(6 ; 7)$ & 0.714 & 0.83 & 72 \\
\hline$B R C A 2$ & $\begin{array}{l}\text { Homologous } \\
\text { recombination }\end{array}$ & Cell-based (V-C8 cells) & Complementation/perturbation & $139(12 ; 13)$ & $\begin{array}{l}1.00 \\
(0.75 \text { to } 1.00)\end{array}$ & $\begin{array}{l}1.00 \\
(0.69 \text { to } 1.00)\end{array}$ & 74 \\
\hline$B R C A 2$ & $\begin{array}{l}\text { Homologous } \\
\text { recombination }\end{array}$ & $\begin{array}{l}\text { Cell-based (mouse ES } \\
\text { cells) }\end{array}$ & Complementation/perturbation & $43(20 ; 15)$ & $\begin{array}{l}1.00 \\
(0.78 \text { to } 1.00)\end{array}$ & $\begin{array}{l}1.00 \\
(0.83 \text { to } 1.00)\end{array}$ & 75 \\
\hline
\end{tabular}

Only assays in which $>30$ variants were tested are listed.

*Known pathogenic and non-pathogenic variants used for estimating sensitivity and specificity are those classified using the multifactorial model as IARC classes $1,2,4$ or $5,{ }^{18}$ unless otherwise indicated.

†As originally published, unless otherwise stated.

fUsed missense variants classified by multifactorial model as IARC classes $1,2,4$ or $5^{18}$ plus the recently classified G1770V variants as pathogenic.

§Used ClinVar as a source of known pathogenic and non-pathogenic variants.

IUsed as non-pathogenic variants alignGVGD grade of C0 and IARC class 1, and as pathogenic variants alignGVGD grade of C35-C65 and IARC class 5.

IARC, International Agency for Research on Cancer.

may be difficult to achieve for genes for which there are very few known pathogenic and non-pathogenic variants to use in a validation set, which will be reflected as wider 95\% CIs.

Controls are critical for validation of assays, assessment of dynamic range, and to determine metrics of performance such as sensitivity and specificity. Some thought should be given to decide on genomic DNA/cDNA/protein sequence that corresponds to the coding sequence in the most commonly found haplotype in non-affected individuals to be used as a reference (wild-type). Note that differences in frequency of common alleles may exist across different populations. This reference cDNA or genomic sequence must be included in every experiment. Variants are scored as having functional impact or not depending on how much they differ from the reference.

It is recommended that within each run of the assay, in addition to the reference sequence, at least one known missense pathogenic and one missense non-pathogenic variant is included. If possible, known missense variants for each protein domain are recommended. To account for the range of variation of nonpathogenic variants, additional known non-pathogenic variants should also be included. Addition of hypomorphic (attenuated) variants with established intermediate risk may help calibration 
of assay results. Concerning VUS in genes for which there are no known missense non-pathogenic and pathogenic variants, alternative approaches, such as the use of missense variants with greater than $1.0 \%$ allele frequency and truncating variants as benign and pathogenic controls, respectively, might provide a yardstick. Results from assays using only truncating variants as pathogenic control should be interpreted with caution as truncating variants may not produce detectable protein, with implications to measuring baseline activity.

\section{LESSONS FROM BRCA1 AND BRCA2 FUNCTIONAL ASSESSMENT}

BRCA1 and BRCA2 have 1863 and 3418 codons, respectively. If we consider all possible single nucleotide changes in these codons, 11015 and 20169 unique missense variants are generated (some changes will result in the same amino acid changes), respectively. Because many have never or only sparsely been observed, we expect that most are rare $(<0.01 \%)$ such that data from functional assays will be required to assess their likelihood of pathogenicity. In order to maximise the chances of identifying pathogenic variants, investigators have focused on functional domains and motifs in which it seems more likely that variants affect protein function. Thus far, most assays have focused on variants at the RING and BRCT domains of BRCA1 and at the DSS1 and DNA interaction domain of BRCA2. ${ }^{910} 3637$ Several functional assays have been described for BRCA1 and BRCA2, but few have tested large (>30) sets of variants (table 2).

For specificity and sensitivity calculations, variants are classified according to a binary classification based on the functional data: functional impact versus no functional impact. Variants with intermediate scores are ignored. This classification is then compared with a binary classification of a reference panel which combines the non-actionable IARC classes 1 and 2 (benign and likely benign) or actionable classes 4 and 5 (likely pathogenic and pathogenic). This simplification allows for the estimation of the assay's ability to correctly identify actionable and nonactionable variants. Most published functional assays have reported high sensitivity and specificity, often close to $100 \%$ (table 2). However, these numbers partially reflect the relatively low numbers of known variants used to assess specificity and sensitivity. To obtain a better sense of an assays performance, it is critical to record and report the lower bounds of the 95\% CI.

Several assays have been developed using yeast (Saccharomyces cerevisiae), which provides a cost-effective and practical platform to evaluate missense variants. However, caution is warranted when interpreting results from model organisms that are cultured at temperatures lower than $37^{\circ} \mathrm{C}$. Some pathogenic variants are relatively stable at lower temperatures $\left(30^{\circ} \mathrm{C}\right.$ vs $37^{\circ} \mathrm{C}$ ) and may score as false negatives, ${ }^{53-55}$ reflected in the assay's slightly lower sensitivity (table 2 ).

It is important to note that contradictory results, for example, a variant scoring pathogenic in a functional assay while being classified by clinical and family data as non-pathogenic, provide opportunities for discovery. BRCA1 variant p.V1736A scored as pathogenic in several functional assays and by in silico prediction tools $^{56}$ despite being classified as non-pathogenic due to a co-occurrence with the known pathogenic p.D821Ifs*25 variant in the same patient. However, on further examination it was found that the carrier presented several features (eg, developmental delay, microcephaly, short stature, very early onset ovarian cancer) pointing at hypomorphic BRCA1 activity. ${ }^{25}$ Detailed genetic and functional investigation of the p.V1736A variant led to the discovery of the first documented carrier of biallelic pathogenic variants in BRCA1. This analysis established the existence of variants with intermediate effects and highlighted the power of functional assessment. ${ }^{25}$

Although there are several missense variants that have displayed intermediate effects in vitro or in mouse models, only three variants, in addition to p.V1736A, have been established as hypomorphic in humans. ${ }^{25} 27$ BRCA1 variant p.R1699Q (c.5096G $>A ; \quad O R=4.29$ ) and $B R C A 2$ variants p.Y3035S (c.9104A $>C ; \quad O R=2.52$ ) and p.G2508S (c.7522G $>A$; $\mathrm{OR}=2.68$ ), have been shown to confer moderate increased risks. There are currently no consensus guidelines about their clinical management but the ENIGMA consortium has recommended breast surveillance for female carriers of p.R1699Q based on mammogram annually from age 40 and bilateral salpingooophorectomy should be considered based on family history. ${ }^{32}$ Care should be exercised in the choice of statistical treatment of the data generated in functional assays. Results from assays are usually normalised using the mean of the activity of the wild-type or reference sequence. Normalisation allows for comparisons across multiple experiments and, in some cases across multiple assays since variant activity is being represented as a percentage of the wild-type activity. Batch effects may be problematic (variance of the wild-type activity across multiple batches should also be taken into account) and some statistical models have taken that in consideration..$^{57}$

A more difficult task is the decision of a specific threshold of activity to separate pathogenic from non-pathogenic variants. Several approaches use arbitrary thresholds (eg, $20 \%$ or $50 \%$ of wild-type activity; number of SD from the wild-type reference; highest activity of a pathogenic variant and lowest activity of a non-pathogenic variant) or linear regression. Recent approaches have moved towards providing a probabilistic interpretation (ie, likelihood of pathogenicity of the variant given the functional data)..$^{5758}$

Probabilistic approaches also provide a path for integration of functional data with other data sources used to classify variants. By generating likelihood ratios (LRs) from the raw or processed functional read-outs (eg, viability counts, luciferase activity, Green Fluorescent Protein intensity), these approaches allow for the incorporation of functional assays as a data source into traditional multifactorial models that have so far not integrated functional data. ${ }^{57}$

Integration of functional data can also be achieved using the ACMG/AMP classification model. According to the ACMG/ AMP, 'well-established assays' can be used to obtain a PS3 or BS3 (strong evidence) criterion but there are no specific guidelines, which are likely to be established by expert panels for each gene. For example, concordant results from at least three independent validated assays would be needed for PS3 or BS3 (strong) criteria, while concordant results in two independent validated assays would generate a PM1 (moderate) criterion.

\section{FUNCTIONAL ASSAYS BASED ON SENSITIVITY TO THERAPEUTIC COMPOUNDS}

Insight in the importance of BRCA1 and BRCA2 for HR led to the development of carrier-specific treatment modalities for breast and ovarian cancers, ${ }^{59-61}$ in particular with the use of PARP inhibitors (PARPi), which are synthetic lethal with BRCA1 or $B R C A 2$ deficiency. The therapeutic window for these types of treatment is greatly increased by the fact that BRCA1 and $B R C A 2$ mutation carriers are generally heterozygous for the pathogenic allele, while tumour cells frequently undergo loss of the wild-type allele. Thus, while the tumour cells are not viable 
in the presence of PARPi, non-tumour cells survive, making the therapy highly effective yet well tolerated.

Because inactivation of the gene product is required both for disruption of HR and sensitivity to PARPi or platinum compounds, functional assays based on sensitivity to these compounds can be used as an indirect read-out for HR to classify germline variants according to their pathogenicity. ${ }^{62}$

In addition to the classification of germline variants according to associated cancer risk, there is an emerging need to classify germline and somatic variants according to their response to PARPi or DNA damaging compounds to predict drug response. PARPi have been approved in the USA and Europe for treatment of advanced and metastatic breast and ovarian cancers. It is unclear the extent to which sensitivity to PARPi or platinum compounds measured in a functional assay predicts in vivo tumour sensitivity. Pathogenic variants conferring high cancer risk with hypomorphic activity towards PARPi response are known to exist. For example, mouse tumour cells carrying the pathogenic Brca1 p.C61G variant showed a poor response to platinum compounds and to PARPi, and resistance rapidly emerged. ${ }^{63}$ Importantly, determining whether a BRCA1 or $B R C A 2$ variant found in tumour tissue confers sensitivity to a given drug may need further clinical information to calibrate the functional assays for this purpose.

Many other genes implicated in HBOC (such as ATM, CHEK2, PALB2 and TP53) are involved in the DNA damage response, suggesting that associated tumours may also have a targetable DNA repair defect. Importantly, recent results from the NOVA, Study 19 and ARIEL3 studies have raised the possibility of a significant benefit of PARPi in ovarian cancer irrespective of BRCA mutation status. ${ }^{64-66}$

\section{FUTURE CHALLENGES AND OPPORTUNITIES}

As we move forward, functional assays should be able to face a significant increase in the number of genes and variants to be analysed for clinical use. The number of alleles for genes predisposing to breast and ovarian cancer is expected to be very large. BRCA1 and BRCA2 have 7898 and 10422 unique alleles documented (table 1; BRCA Exchange: http://brcaexchange.org/) and other HBOC genes are expected to significantly add to the number of predisposing alleles. In addition, recent systematic germline sequencing efforts of breast and ovarian cancer cases are expected to reveal additional genes and variants associated with risk.

To face the rapid increase in variants, high-throughput functional assays that can generate and analyse large numbers of variants have been developed for BRCA1. ${ }^{9}{ }^{10}$ Initially, these consisted of the large-scale generation and analysis of ectopically expressed cDNA constructs. Recent development of CRISPR-assisted gene targeting has now also allowed saturated mutagenesis at endogenous loci, exemplified by high-troughput mutagenesis of the BRCA1 RING and BRCT domains in haploid cells. ${ }^{9}{ }^{10}$ Likewise, assays based on human primary cells from carriers may also be used to capture more subtle functional defects that depend on the carrier's genetic background, but may be less amenable to highthroughput approaches. ${ }^{42}$ Such high-throughput approaches can provide catalogues of potentially pathogenic variants that can aid in the interpretation of newly observed VUS. CRISPRassisted gene targeting is also expected to accelerated the pace at which mouse models can be generated. ${ }^{67} 68$

The path to clinical implementation will necessarily involve the inclusion of clinically calibrated functional data into comprehensive multifactorial statistical models. Functional assays are specialised tests that most diagnostic testing laboratories are currently not able to provide. In the USA, results from such tests cannot be directly used for clinical decisions unless they are conducted under Clinical Laboratory Improvement Amendments guidelines. However, if data have been validated (ie, evaluated for a comprehensive series of performance metrics such as sensitivity, specificity, accuracy, precision, repeatability and robustness), functional assays reported from research labs can be used as evidence for clinical annotation. ${ }^{7}$ It is important to consider that mistakes may occur in the processing of a sample in the absence of standard operating procedures. Those mistakes include clerical mistakes in reports (eg, reporting pathogenic when it should be non-pathogenic), sample swapping, errors in measurements due to lack of equipment calibration or improper staff training. Thus, evidence from functional studies performed in a research setting must be carefully verified to determine data quality, reliability and the degree of confidence in the results. In the context of risk assessment, we caution against the use of functional data as the sole source of information for clinical recommendations. Despite these challenges, the value of functional assessment of variants to improve cancer care, based on international and multidisciplinary collaborations, is expected to be high and therefore we envisage the clinical implementation of functional assays for classification of VUS to proceed at an accelerated pace.

\section{Author affiliations}

${ }^{1}$ Cancer Epidemiology, H. Lee Moffitt Cancer Center and Research Institute, Tampa, Florida, USA

${ }^{2}$ Division of Molecular Pathology, Oncode Institute, The Netherlands Cancer Institute, Amsterdam, The Netherlands

${ }^{3}$ Cancer Sciences, University of Southampton Faculty of Medicine, Southampton, UK ${ }^{4}$ Hub-DBC, Institut Pasteur, USR 3756 CNRS, Paris, France

${ }^{5} \mathrm{CHU}$ de Québec-Université Laval, Oncology Division, Laval University Cancer

Research Center, Quebec City, Quebec, Canada

${ }^{6}$ National Cancer Institute at Frederick, Frederick, Maryland, USA

${ }^{7}$ Beth Israel Deaconess Medical Center, Boston, Massachusetts, USA

${ }^{8}$ Ulm University, Ulm, Baden-Württemberg, Germany

${ }^{9}$ Mayo Clinic, Rochester, Minnesota, USA

${ }^{10}$ Human Genetics, Leiden University Medical Center, Leiden, The Netherlands

\section{Twitter Alvaro N Monteiro @AccidentalGenet}

Acknowledgements The authors would like to thank Amanda Spurdle for helpful discussions.

Contributors This manuscript emerged from discussions held at a Netherlands Cancer Institute (NKI) workshop on Functional Analysis of Sequence Variants in Hereditary Breast and Ovarian Cancer Genes (Amsterdam, The Netherlands). AM and MV planned the study and coordinated the discussions and are responsible for the overall content as guarantors. All authors contributed to the discussions, to the preparation and editing of the manuscript, reviewed and approved the final manuscript.

Funding The meeting was supported by funds from the Cancer Genomics Center Netherlands through the Netherlands Organization for Scientific Research (NWO), the Royal Netherlands Academy of Arts and Sciences (KNAW), the Danish Counsil for Independent Research (DFF), the Netherlands Cancer Institute and from IDT and BIOKÉ.

Competing interests LW is an inventor and owner of a patent on a test system for determining genotoxicities and cancer risk.

Patient consent for publication Not required.

Provenance and peer review Not commissioned; externally peer reviewed.

\section{ORCID iDs}

Alvaro N Monteiro http://orcid.org/0000-0002-8448-4801

Peter Bouwman http://orcid.org/0000-0003-0920-8433

Arne N Kousholt http://orcid.org/0000-0002-3972-1740

Diana M Eccles http://orcid.org/0000-0002-9935-3169

Gael A Millot http://orcid.org/0000-0002-0591-3509

Jean-Yves Masson http://orcid.org/0000-0002-4403-7169

Marjanka K Schmidt http://orcid.org/0000-0002-2228-429X 
Shyam K Sharan http://orcid.org/0000-0002-9333-870X

Ralph Scully http://orcid.org/0000-0002-5064-0175

Lisa Wiesmüller http://orcid.org/0000-0002-2397-5041

Fergus Couch http://orcid.org/0000-0001-9417-9985

Maaike P G Vreeswijk http://orcid.org/0000-0003-4068-9271

\section{REFERENCES}

1 Miki Y, Swensen J, Shattuck-Eidens D, Futreal P, Harshman K, Tavtigian S, Liu Q, Cochran C, Bennett L, Ding W, et al. A strong candidate for the breast and ovarian cancer susceptibility gene BRCA1. Science 1994;266:66-71.

2 Wooster R, Bignell G, Lancaster J, Swift S, Seal S, Mangion J, Collins N, Gregory S, Gumbs C, Micklem G, Barfoot R, Hamoudi R, Patel S, Rices C, Biggs P, Hashim Y, Smith A, Connor F, Arason A, Gudmundsson J, Ficenec D, Kelsell D, Ford D, Tonin P, Timothy Bishop D, Spurr NK, Ponder BAJ, Eeles R, Peto J, Devilee P, Cornelisse C, Lynch $H$, Narod S, Lenoir G, Egilsson V, Bjork Barkadottir R, Easton DF, Bentley DR, Futreal PA, Ashworth A, Stratton MR. Identification of the breast cancer susceptibility gene BRCA2. Nature 1995;378:789-92.

3 Easton DF, Pharoah PDP, Antoniou AC, Tischkowitz M, Tavtigian SV, Nathanson KL, Devilee P, Meindl A, Couch FJ, Southey M, Goldgar DE, Evans DGR, Chenevix-Trench G, Rahman N, Robson M, Domchek SM, Foulkes WD. Gene-panel sequencing and the prediction of breast-cancer risk. N Engl J Med 2015;372:2243-57.

4 Narod SA, Offit K. Prevention and management of hereditary breast cancer. J Clin Oncol 2005;23:1656-63.

5 Campeau PM, Foulkes WD, Tischkowitz MD. Hereditary breast cancer: new genetic developments, new therapeutic avenues. Hum Genet 2008:124:31-42.

6 Kurian AW, Gong GD, John EM, Johnston DA, Felberg A, West DW, Miron A, Andrulis IL, Hopper JL, Knight JA, Ozcelik H, Dite GS, Apicella C, Southey MC, Whittemore AS. Breast cancer risk for noncarriers of family-specific BRCA1 and BRCA2 mutations: findings from the breast cancer family registry. J Clin Oncol 2011;29:4505-9.

7 Richards S, Aziz N, Bale S, Bick D, Das S, Gastier-Foster J, Grody WW, Hegde M, Lyon E, Spector E, Voelkerding K, Rehm HL, ACMG Laboratory Quality Assurance Committee. Standards and guidelines for the interpretation of sequence variants: a joint consensus recommendation of the American College of medical genetics and genomics and the association for molecular pathology. Genet Med 2015; 17:405-23.

8 Matreyek KA, Starita LM, Stephany JJ, Martin B, Chiasson MA, Gray VE, Kircher M, Khechaduri A, Dines JN, Hause RJ, Bhatia S, Evans WE, Relling MV, Yang W, Shendure J, Fowler DM. Multiplex assessment of protein variant abundance by massively parallel sequencing. Nat Genet 2018;50:874-82.

9 Starita LM, Islam MM, Banerjee T, Adamovich Al, Gullingsrud J, Fields S, Shendure J, Parvin JD. A multiplex homology-directed DNA repair assay reveals the impact of more than 1,000 BRCA1 missense substitution variants on protein function. Am J Hum Genet 2018;103:498-508.

10 Findlay GM, Daza RM, Martin B, Zhang MD, Leith AP, Gasperini M, Janizek JD, Huang $X$, Starita LM, Shendure J. Accurate classification of BRCA1 variants with saturation genome editing. Nature 2018;562:217-22.

11 Lee K, Seifert BA, Shimelis H, Ghosh R, Crowley SB, Carter NJ, Doonanco K, Foreman AK, Ritter DI, Jimenez S, Trapp M, Offit K, Plon SE, Couch FJ. Clinical validity assessment of genes frequently tested on hereditary breast and ovarian cancer susceptibility sequencing panels. Genet Med 2019;21:1497-506.

12 Shimelis H, LaDuca H, Hu C, Hart SN, Na J, Thomas A, Akinhanmi M, Moore RM, Brauch H, Cox A, Eccles DM, Ewart-Toland A, Fasching PA, Fostira F, Garber J, Godwin AK, Konstantopoulou I, Nevanlinna H, Sharma P, Yannoukakos D, Yao S, Feng B-J, Tippin Davis B, Lilyquist J, Pesaran T, Goldgar DE, Polley EC, Dolinsky JS, Couch FJ. Triple-Negative breast cancer risk genes identified by multigene hereditary cance panel testing. J Nat/ Cancer Inst 2018;110:855-62.

13 Couch FJ, Shimelis H, Hu C, Hart SN, Polley EC, Na J, Hallberg E, Moore R, Thomas A, Lilyquist J, Feng B, McFarland R, Pesaran T, Huether R, LaDuca H, Chao EC, Goldgar $\mathrm{DE}$, Dolinsky JS. Associations between cancer predisposition testing panel genes and breast cancer. JAMA Oncol 2017;3:1190-6.

14 Jones MR, Kamara D, Karlan BY, Pharoah PDP, Gayther SA. Genetic epidemiology of ovarian cancer and prospects for polygenic risk prediction. Gynecol Oncol 2017;147:705-13.

15 Lilyquist J, LaDuca H, Polley E, Davis BT, Shimelis H, Hu C, Hart SN, Dolinsky JS, Couch FJ, Goldgar DE. Frequency of mutations in a large series of clinically ascertained ovarian cancer cases tested on multi-gene panels compared to reference controls. Gynecol Oncol 2017;147:375-80.

16 Oren M, Rotter V. Mutant p53 gain-of-function in cancer. Cold Spring Harb Perspect Biol 2010;2:a001107.

17 Easton DF, Deffenbaugh AM, Pruss D, Frye C, Wenstrup RJ, Allen-Brady K, Tavtigian SV Monteiro ANA, Iversen ES, Couch FJ, Goldgar DE. A systematic genetic assessment of 1,433 sequence variants of unknown clinical significance in the BRCA1 and BRCA2 breast cancer-predisposition genes. Am J Hum Genet 2007;81:873-83.

18 Plon SE, Eccles DM, Easton D, Foulkes WD, Genuardi M, Greenblatt MS, Hogervorst FBL, Hoogerbrugge N, Spurdle AB, Tavtigian SV, IARC Unclassified Genetic Variants Working Group. Sequence variant classification and reporting: recommendations for improving the interpretation of cancer susceptibility genetic test results. Hum Mutat 2008;29:1282-91.
19 Ernst C, Hahnen E, Engel C, Nothnagel M, Weber J, Schmutzler RK, Hauke J. Performance of in silico prediction tools for the classification of rare BRCA1/2 missense variants in clinical diagnostics. BMC Med Genomics 2018;11:35.

20 Hart SN, Hoskin T, Shimelis H, Moore RM, Feng B, Thomas A, Lindor NM, Polley EC, Goldgar DE, Iversen E, Monteiro ANA, Suman VJ, Couch FJ. Comprehensive annotation of BRCA1 and BRCA2 missense variants by functionally validated sequence-based computational prediction models. Genet Med 2019;21:71-80.

21 Tavtigian SV, Greenblatt MS, Lesueur F, Byrnes GB, Group IUGVW. In silico analysis of missense substitutions using sequence-alignment based methods. Hum Mutat 2008;29:1327-36.

22 Thompson BA, Greenblatt MS, Vallee MP, Herkert JC, Tessereau C, Young EL, Adzhubey IA, Li B, Bell R, Feng B, Mooney SD, Radivojac P, Sunyaev SR, Frebourg T, Hofstra RMW, Sijmons RH, Boucher K, Thomas A, Goldgar DE, Spurdle AB, Tavtigian SV. Calibration of multiple in silico tools for predicting pathogenicity of mismatch repair gene missense substitutions. Hum Mutat 2013:34:255-65.

23 Hicks S, Wheeler DA, Plon SE, Kimmel M. Prediction of missense mutation functionality depends on both the algorithm and sequence alignment employed. Hum Mutat 2011;32:661-8.

24 Kondrashov AS, Sunyaev S, Kondrashov FA. Dobzhansky-Muller incompatibilities in protein evolution. Proc Natl Acad Sci U S A 2002;99:14878-83.

25 Domchek SM, Tang J, Stopfer J, Lilli DR, Hamel N, Tischkowitz M, Monteiro ANA, Messick TE, Powers J, Yonker A, Couch FJ, Goldgar DE, Davidson HR, Nathanson KL, Foulkes WD, Greenberg RA. Biallelic Deleterious BRCA1 Mutations in a Woman with Early-Onset Ovarian Cancer. Cancer Discov 2013;3:399-405.

26 Spurdle AB, Whiley PJ, Thompson B, Feng B, Healey S, Brown MA, Pettigrew C, Van Asperen CJ, Ausems MGEM, Kattentidt-Mouravieva AA, van den Ouweland AMW Belgium UV Consortium D, Lindblom A, Pigg MH, Schmutzler RK, Engel C, Meindl A, Caputo S, Sinilnikova OM, Lidereau R, Couch FJ, Guidugli L, Hansen TvanO Thomassen M, Eccles DM, Tucker K, Benitez J, Domchek SM, Toland AE, Van Rensburg EJ, Wappenschmidt B, Borg Åke, Vreeswijk MPG, Goldgar DE. Brca1 R1699Q variant displaying ambiguous functional abrogation confers intermediate breast and ovarian cancer risk. J Med Genet 2012;49:525-32.

27 Shimelis H, Mesman RLS, Von Nicolai C, Ehlen A, Guidugli L, Martin C, Calléja FMGR, Meeks H, Hallberg E, Hinton J, Lilyquist J, Hu C, Aalfs CM, Aittomäki K, Andrulis I, Anton-Culver H, Arndt V, Beckmann MW, Benitez J, Bogdanova NV, Bojesen SE, Bolla MK, Borresen-Dale A-L, Brauch H, Brennan P, Brenner H, Broeks A, Brouwers B, Brüning T, Burwinkel B, Chang-Claude J, Chenevix-Trench G, Cheng C-Y, Choi J-Y, Collée JM, Cox A, Cross SS, Czene K, Darabi H, Dennis J, Dörk T, Dos-SantosSilva I, Dunning AM, Fasching PA, Figueroa J, Flyger H, García-Closas M, Giles GG, Glendon G, Guénel P, Haiman CA, Hall P, Hamann U, Hartman M, Hogervorst FB, Hollestelle A, Hopper JL, Ito H, Jakubowska A, Kang D, Kosma V-M, Kristensen V, Lai K-N, Lambrechts D, Marchand LL, Li J, Lindblom A, Lophatananon A, Lubinski J, Machackova E, Mannermaa A, Margolin S, Marme F, Matsuo K, Miao H, Michailidou K, Milne RL, Muir K, Neuhausen SL, Nevanlinna H, Olson JE, Olswold C, Oosterwijk JJC, Osorio A, Peterlongo P, Peto J, Pharoah PDP, Pylkäs K, Radice P, Rashid MU, Rhenius V, Rudolph A, Sangrajrang S, Sawyer EJ, Schmidt MK, Schoemaker MJ, Seynaeve C, Shah M, Shen C-Y, Shrubsole M, Shu X-O, Slager S, Southey MC, Stram DO, Swerdlow A, Teo SH, Tomlinson I, Torres D, Truong T, van Asperen CJ, van der Kolk LE, Wang Q, Winqvist R, Wu AH, Yu J-C, Zheng W, Zheng Y, Leary J, Walker L, Foretova L, Fostira F, Claes KBM, Varesco L, Moghadasi S, Easton DF, Spurdle A, Devilee P, Vrieling $\mathrm{H}$, Monteiro ANA, Goldgar DE, Carreira A, Vreeswijk MPG, Couch FJ, for kConFab/AOCS Investigators, for NBCS Collaborators. BRCA2 Hypomorphic Missense Variants Confer Moderate Risks of Breast Cancer. Cancer Res 2017;77:2789-99.

28 Meeks HD, Song H, Michailidou K, Bolla MK, Dennis J, Wang Q, Barrowdale D, Frost D, McGuffog L, Ellis S, Feng B, Buys SS, Hopper JL, Southey MC, Tesoriero A, James PA, Bruinsma F, Campbell IG, Broeks A, Schmidt MK, Hogervorst FBL, Beckman MW, Fasching PA, Fletcher O, Johnson N, Sawyer EJ, Riboli E, Banerjee S, Menon U, Tomlinson I, Burwinkel B, Hamann U, Marme F, Rudolph A, Janavicius R, Tihomirova L, Tung N, Garber J, Cramer D, Terry KL, Poole EM, Tworoger SS, Dorfling CM, van Rensburg EJ, Godwin AK, Guénel P, Truong T, Stoppa-Lyonnet D, Damiola F, Mazoyer S, Sinilnikova OM, Isaacs C, Maugard C, Bojesen SE, Flyger H, Gerdes A-M, Hansen TVO, Jensen A, Kjaer SK, Hogdall C, Hogdall E, Pedersen IS, Thomassen M, Benitez J, González-Neira A, Osorio A, Hoya Mdela, Segura PP, Diez O, Lazaro C, Brunet J, AntonCulver $H$, Eunjung L, John EM, Neuhausen SL, Ding YC, Castillo D, Weitzel JN, Ganz PA, Nussbaum RL, Chan SB, Karlan BY, Lester J, Wu A, Gayther S, Ramus SJ, Sieh W, Whittermore AS, Monteiro ANA, Phelan CM, Terry MB, Piedmonte M, Offit K, Robson M, Levine D, Moysich KB, Cannioto R, Olson SH, Daly MB, Nathanson KL, Domchek SM, Lu KH, Liang D, Hildebrant MAT, Ness R, Modugno F, Pearce L, Goodman MT, Thompson PJ, Brenner H, Butterbach K, Meindl A, Hahnen E, Wappenschmidt B, Brauch H, Brüning T, Blomqvist C, Khan S, Nevanlinna H, Pelttari LM, Aittomäki K, Butzow R, Bogdanova NV, Dörk T, Lindblom A, Margolin S, Rantala J, Kosma V-M, Mannermaa A, Lambrechts D, Neven P, Claes KBM, Maerken TV, Chang-Claude J, Flesch-Janys D, Heitz F, Varon-Mateeva R, Peterlongo P, Radice P, Viel A, Barile M, Peissel B, Manoukian S, Montagna M, Oliani C, Peixoto A, Teixeira MR, Collavoli A, Hallberg E, Olson JE, Goode EL, Hart SN, Shimelis H, Cunningham JM, Giles GG, Milne RL, Healey S, Tucker K, Haiman CA, Henderson BE, Goldberg MS, Tischkowitz M, Simard J, Soucy P, Eccles DM, Le N, Borresen-Dale A-L, Kristensen V, Salvesen HB, Bjorge L, Bandera EV, Risch H, Zheng W, Beeghly-Fadiel A, Cai H, Pylkäs K, Tollenaar 
RAEM, Ouweland AMWvander, Andrulis IL, Knight JA, Narod S, Devilee P, Winqvist R, Figueroa J, Greene MH, Mai PL, Loud JT, García-Closas M, Schoemaker MJ, Czene K, Darabi H, McNeish I, Siddiquil N, Glasspool R, Kwong A, Park SK, Teo SH, Yoon S-Y, Matsuo K, Hosono S, Woo YL, Gao Y-T, Foretova L, Singer CF, Rappaport-Feurhauser C, Friedman E, Laitman Y, Rennert G, Imyanitov EN, Hulick PJ, Olopade OI, Senter L, Olah E, Doherty JA, Schildkraut J, Koppert LB, Kiemeney LA, Massuger LFAG, Cook LS, Pejovic T, Li J, Borg A, Öfverholm A, Rossing MA, Wentzensen N, Henriksson K, Cox A, Cross SS, Pasini BJ, Shah M, Kabisch M, Torres D, Jakubowska A, Lubinski J, Gronwald J, Agnarsson BA, Kupryjanczyk J, Moes-Sosnowska J, Fostira F, Konstantopoulou I, Slager S, Jones M, Antoniou AC, Berchuck A, Swerdlow A, Chenevix-Trench G, Dunning AM, Pharoah PDP, Hall P, Easton DF, Couch FJ, Spurdle AB, Goldgar DE, EMBRACE, kConFab Investigators, Australia Ovarian Cancer Study Group, HEBON, GEMO Study Collaborators, OCGN, PRostate cancer AssoCiation group To Investigate Cancer Associated aLterations in the genome. Brca2 polymorphic stop codon K3326X and the risk of breast, prostate, and ovarian cancers. J Natl Cancer Inst 2016;108:djv315.

29 Woods NT, Baskin R, Golubeva V, Jhuraney A, De-Gregoriis G, Vaclova T, Goldgar DE, Couch FJ, Carvalho MA, Iversen ES, Monteiro AN, Couch D.E.;, Carvalho FJ, Iversen MA. Functional assays provide a robust tool for the clinical annotation of genetic variants of uncertain significance. NPJ Genom Med 201610.1038/npjgenmed.2016.1. [Epub ahead of print: 02 Mar 2016].

30 Guidugli L, Pankratz VS, Singh N, Thompson J, Erding CA, Engel C, Schmutzler R, Domchek S, Nathanson K, Radice P, Singer C, Tonin PN, Lindor NM, Goldgar DE, Couch FJ. A Classification Model for BRCA2 DNA Binding Domain Missense Variants Based on Homology-Directed Repair Activity. Cancer Res 2013;73:265-75.

31 Spurdle AB, Greville-Heygate S, Antoniou AC, Brown M, Burke L, de la Hoya M, Domchek S, Dörk T, Firth HV, Monteiro AN, Mensenkamp A, Parsons MT, Radice P, Robson M, Tischkowitz M, Tudini E, Turnbull C, Vreeswijk MP, Walker LC, Tavtigian S, Eccles DM. Towards controlled terminology for reporting germline cancer susceptibility variants: an enigma report. J Med Genet 2019;56:347-57.

32 Moghadasi S, Meeks HD, Vreeswijk MPG, Janssen LAM, Borg Åke, Ehrencrona $H$, Paulsson-Karlsson Y, Wappenschmidt B, Engel C, Gehrig A, Arnold N, Hansen TVO, Thomassen M, Jensen UB, Kruse TA, Ejlertsen B, Gerdes A-M, Pedersen IS, Caputo SM, Couch F, Hallberg EJ, van den Ouweland AMW, Collée MJ, Teugels E, Adank MA, van der Luijt RB, Mensenkamp AR, Oosterwijk JC, Blok MJ, Janin $\mathrm{N}$, Claes KBM, Tucker K, Viassolo V, Toland AE, Eccles DE, Devilee P, Van Asperen CJ, Spurdle AB, Goldgar DE, García EG. The BRCA1 c. 5096G>A p.Arg1699GIn (R1699Q) intermediate risk variant: breast and ovarian cancer risk estimation and recommendations for clinical management from the ENIGMA consortium. J Med Genet 2018;55:15-20.

33 The Gene Ontology Consortium. Expansion of the gene ontology knowledgebase and resources. Nucleic Acids Res 2017:45:D331-8.

34 Thomassen M, Blanco A, Montagna M, Hansen TVO, Pedersen IS, Gutiérrez-Enríquez S, Menéndez M, Fachal L, Santamariña M, Steffensen AY, Jønson L, Agata S, Whiley P, Tognazzo S, Tornero E, Jensen UB, Balmaña J, Kruse TA, Goldgar DE, Lázaro C, Diez 0 , Spurdle AB, Vega A. Characterization of BRCA1 and BRCA2 splicing variants: a collaborative report by enigma Consortium members. Breast Cancer Res Treat 2012;132:1009-23.

35 Walker LC, Whiley PJ, Couch FJ, Farrugia DJ, Healey S, Eccles DM, Lin F, Butler SA, Goff SA, Thompson BA, Lakhani SR, Da Silva LM, Tavtigian SV, Goldgar DE, Brown MA, Spurdle AB. Detection of splicing aberrations caused by BRCA1 and BRCA2 sequence variants encoding missense substitutions: implications for prediction of pathogenicity. Hum Mutat 2010;31:E1484-505.

36 Guidugli L, Carreira A, Caputo SM, Ehlen A, Galli A, Monteiro ANA, Neuhausen SL, Hansen TVO, Couch FJ, Vreeswijk MPG, consortium E, ENIGMA consortium. Functional assays for analysis of variants of uncertain significance in BRCA2. Hum Mutat 2014;35:151-64.

37 Millot GA, Carvalho MA, Caputo SM, Vreeswijk MPG, Brown MA, Webb M, Rouleau E, Neuhausen SL, Hansen TvO, Galli A, Brandão RD, Blok MJ, Velkova A, Couch FJ, Monteiro ANA, on behalf of the ENIGMA (Evidence-based Network for the Interpretation of Germline Mutant Alleles) Consortium Functional Assay Working Group. A guide for functional analysis of $B R C A 1$ variants of uncertain significance. Hum Mutat 2012;33:1526-37.

38 Jhuraney A, Velkova A, Johnson RC, Kessing B, Carvalho RS, Whiley P, Spurdle AB, Vreeswijk MPG, Caputo SM, Millot GA, Vega A, Coquelle N, Galli A, Eccles D, Blok MJ, Pal T, van der Luijt RB, Santamariña Pena M, Neuhausen SL, Donenberg T, Machackova E, Thomas S, Vallée M, Couch FJ, Tavtigian SV, Glover JNM, Carvalho MA, Brody LC, Sharan SK, Monteiro AN, Evidence-based Network for the Interpretation of Germline Mutant Alleles Consortium. Brca1 Circos: a visualisation resource for functional analysis of missense variants. J Med Genet 2015;52:224-30.

39 Fernandes VC, Golubeva VA, Di Pietro G, Shields C, Amankwah K, Nepomuceno TC, de Gregoriis G, Abreu RBV, Harro C, Gomes TT, Silva RF, Suarez-Kurtz G, Couch FJ, Iversen ES, Monteiro ANA, Carvalho MA. Impact of amino acid substitutions at secondary structures in the BRCT domains of the tumor suppressor BRCA1: implications for clinical annotation. J Biol Chem 2019;294:5980-92.

40 Kato S, Han S-Y, Liu W, Otsuka K, Shibata H, Kanamaru R, Ishioka C. Understanding the function-structure and function-mutation relationships of p53 tumor suppressor protein by high-resolution missense mutation analysis. Proc Natl Acad Sci U SA 2003; 100:8424-9.
41 Bell DW, Kim SH, Godwin AK, Schiripo TA, Harris PL, Haserlat SM, Wahrer DCR, Haiman CA, Daly MB, Niendorf KB, Smith MR, Sgroi DC, Garber JE, Olopade OI, Le Marchand L, Henderson BE, Altshuler D, Haber DA, Freedman ML. Genetic and functional analysis of CHEK2 (Chk2) variants in multiethnic cohorts. Int J Cancer 2007;121:2661-7.

42 Keimling M, Volcic M, Csernok A, Wieland B, Dörk T, Wiesmüller L. Functional characterization connects individual patient mutations in ataxia telangiectasia mutated (ATM) with dysfunction of specific DNA double-strand break-repair signaling pathways. Faseb J 2011;25:3849-60.

43 Desrichard A, Bidet Y, Uhrhammer N, Bignon Y-J. Chek2 contribution to hereditary breast cancer in non-BRCA families. Breast Cancer Res 2011;13.

44 Caleca L, Catucci I, Figlioli G, De Cecco L, Pesaran T, Ward M, Volorio S, Falanga A, Marchetti M, Iascone M, Tondini C, Zambelli A, Azzollini J, Manoukian S, Radice P, Peterlongo $P$. Two missense variants detected in breast cancer probands preventing BRCA2-PALB2 protein interaction. Front Oncol 2018:8:480.

45 Obermeier K, Sachsenweger J, Friedl TWP, Pospiech H, Winqvist R, Wiesmüller L. Heterozygous PALB2 c.1592delT mutation channels DNA double-strand break repair into error-prone pathways in breast cancer patients. Oncogene 2016;35:3796-806.

46 Pauty J, Couturier AM, Rodrigue A, Caron M-C, Coulombe Y, Dellaire G, Masson J-Y. Cancer-Causing mutations in the tumor suppressor PALB2 reveal a novel cancer mechanism using a hidden nuclear export signal in the WD40 repeat motif. Nucleic Acids Res 2017:45:2644-57.

47 Shakya R, Reid LJ, Reczek CR, Cole F, Egli D, Lin C-S, deRooij DG, Hirsch S, Ravi K, Hicks JB, Szabolcs M, Jasin M, Baer R, Ludwig T. Brca1 tumor suppression depends on BRCT phosphoprotein binding, but not its E3 ligase activity. Science 2011;334:525-8

48 Drost R, Dhillon KK, van der Gulden H, van der Heijden I, Brandsma I, Cruz C, Chondronasiou D, Castroviejo-Bermejo M, Boon U, Schut E, van der Burg E, Wientjens E, Pieterse M, Klijn C, Klarenbeek S, Loayza-Puch F, Elkon R, van Deemter $\mathrm{L}$, Rottenberg S, van de Ven M, Dekkers DHW, Demmers JAA, van Gent DC, Agami R, Balmaña J, Serra V, Taniguchi T, Bouwman P, Jonkers J. BRCA1185delAG tumors may acquire therapy resistance through expression of RING-less BRCA1. J Clin Invest 2016;126:2903-18.

49 Wang Y, Krais JJ, Bernhardy AJ, Nicolas E, Cai KQ, Harrell MI, Kim HH, George E, Swisher EM, Simpkins F, Johnson N. Ring domain-deficient BRCA1 promotes PARP inhibitor and platinum resistance. J Clin Invest 2016;126:3145-57.

50 Hartford SA, Chittela R, Ding X, Vyas A, Martin B, Burkett S, Haines DC, Southon $E$, Tessarollo L, Sharan SK. Interaction with PALB2 is essential for maintenance of genomic integrity by BRCA2. PLoS Genet 2016;12:e1006236.

51 Thirthagiri E, Klarmann KD, Shukla AK, Southon E, Biswas K, Martin BK, North SL, Magidson V, Burkett S, Haines DC, Noer K, Matthai R, Tessarollo L, Loncarek J, Keller JR, Sharan SK. Brca2 minor transcript lacking exons 4-7 supports viability in mice and may account for survival of humans with a pathogenic biallelic mutation. Hum Mol Genet 2016:25:1934-45.

52 Parsons MT, Tudini E, Li H, Hahnen E, Wappenschmidt B, Feliubadaló L, Aalfs CM, Agata S, Aittomäki K, Alducci E, Alonso-Cerezo MC, Arnold N, Auber B, Austin R, Azzollini J, Balmaña J, Barbieri E, Bartram CR, Blanco A, Blümcke B, Bonache $S$, Bonanni B, Borg Åke, Bortesi B, Brunet J, Bruzzone C, Bucksch K, Cagnoli G, Caldés T, Caliebe A, Caligo MA, Calvello M, Capone GL, Caputo SM, Carnevali I, Carrasco E, Caux-Moncoutier V, Cavalli P, Cini G, Clarke EM, Concolino P, Cops EJ, Cortesi L, Couch FJ, Darder E, Hoya M, Dean M, Debatin I, Del Valle J, Delnatte C, Derive N, Diez O, Ditsch N, Domchek SM, Dutrannoy V, Eccles DM, Ehrencrona H, Enders U, Evans DG, Farra C, Faust U, Felbor U, Feroce I, Fine M, Foulkes WD, Galvao HCR, Gambino G, Gehrig A, Gensini F, Gerdes Anne-Marie, Germani A, Giesecke J, Gismondi V, Gómez C, Garcia EB, González S, Grau E, Grill S, Gross E, Guerrieri-Gonzaga A, GuillaudBataille M, Gutiérrez-Enríquez S, Haaf T, Hackmann K, Hansen TVO, Harris M, Hauke J, Heinrich T, Hellebrand H, Herold KN, Honisch E, Horvath J, Houdayer C, Hübbel V, Iglesias S, Izquierdo A, James PA, Janssen LAM, Jeschke U, Kaulfuß S, Keupp K, Kiechle M, Kölbl A, Krieger S, Kruse TA, Kvist A, Lalloo F, Larsen M, Lattimore VL, Lautrup C, Ledig S, Leinert E, Lewis AL, Lim J, Loeffler M, López-Fernández A, Lucci-Cordisco E, Maass N, Manoukian S, Marabelli M, Matricardi L, Meindl A, Michelli RD, Moghadasi S, Moles-Fernández A, Montagna M, Montalban G, Monteiro AN, Montes E, Mori L, Moserle L, Müller CR, Mundhenke C, Naldi N, Nathanson KL, Navarro M, Nevanlinna $\mathrm{H}$, Nichols CB, Niederacher D, Nielsen HR, Ong Kai-ren, Pachter N, Palmero El, Papi L, Pedersen IS, Peissel B, Perez-Segura P, Pfeifer K, Pineda M, Pohl-Rescigno E, Poplawski NK, Porfirio B, Quante AS, Ramser J, Reis RM, Revillion F, Rhiem K, Riboli B, Ritter J, Rivera D, Rofes P, Rump A, Salinas M, Sánchez de Abajo AM, Schmidt G, Schoenwiese U, Seggewiß J, Solanes A, Steinemann D, Stiller M, Stoppa-Lyonnet D, Sullivan KJ, Susman R, Sutter C, Tavtigian SV, Teo SH, Teulé A, Thomassen M, Tibiletti MG, Tischkowitz M, Tognazzo S, Toland AE, Tornero E, Törngren T, Torres-Esquius S, Toss A, Trainer AH, Tucker KM, Asperen CJ, Mackelenbergh MT, Varesco L, Vargas-Parra G, Varon R, Vega A, Velasco Ángela, Vesper Anne-Sophie, Viel A, Vreeswijk MPG, Wagner SA, Waha A, Walker LC, Walters RJ, Wang-Gohrke S, Weber BHF, Weichert W, Wieland K, Wiesmüller L, Witzel I, Wöckel A, Woodward ER, Zachariae S, Zampiga V, Zeder-Göß C, Investigators KConFab, Lázaro C, Nicolo A, Radice P, Engel C, Schmutzler RK, Goldgar DE, Spurdle AB. Large scale multifactorial likelihood quantitative analysis of $B R C A 1$ and $B R C A 2$ variants: An ENIGMA resource to support clinical variant classification. Hum Mutat 2019;40:1557-78 
53 Worley T, Vallon-Christersson J, Billack B, Borg A, Monteiro ANA. A naturally occurring allele of BRCA1 coding for a temperature-sensitive mutant protein. Cancer Biol Ther 2002;1:497-501.

54 Lovelock PK, Spurdle AB, Mok MTS, Farrugia DJ, Lakhani SR, Healey S, Arnold S, Buchanan D, Investigators kConFab, Couch FJ, Henderson BR, Goldgar DE, Tavtigian SV, Chenevix-Trench G, Brown MA. Identification of BRCA1 missense substitutions that confer partial functional activity: potential moderate risk variants? Breast Cancer Research 2007;9:R82.

55 Millot GA, Berger A, Lejour V, Boulé J-B, Bobo C, Cullin C, Lopes J, Stoppa-Lyonnet D, Nicolas A. Assessment of human nter and cter BRCA1 mutations using growth and localization assays in yeast. Hum Mutat 2011;32:1470-80.

56 Lee MS, Green R, Marsillac SM, Coquelle N, Williams RS, Yeung T, Foo D, Hau DD, Hui B, Monteiro ANA, Glover JNM. Comprehensive analysis of missense variations in the BRCT domain of BRCA1 by structural and functional assays. Cancer Res 2010:70:4880-90.

57 Iversen ES, Couch FJ, Goldgar DE, Tavtigian SV, Monteiro ANA. A computational method to classify variants of uncertain significance using functional assay data with application to BRCA1. Cancer Epidemiol Biomarkers Prev 2011;20:1078-88.

58 Thouvenot P, Ben Yamin B, Fourrière L, Lescure A, Boudier T, Del Nery E, Chauchereau A, Goldgar DE, Houdayer C, Stoppa-Lyonnet D, Nicolas A, Millot GA. Functional assessment of genetic variants with outcomes adapted to clinical decision-making. PLoS Genet 2016;12:e1006096.

59 Rottenberg S, Jaspers JE, Kersbergen A, van der Burg E, Nygren AOH, Zander SAL, Derksen PWB, de Bruin M, Zevenhoven J, Lau A, Boulter R, Cranston A, O'Connor MJ, Martin NMB, Borst P, Jonkers J. High sensitivity of Brca1-deficient mammary tumors to the PARP inhibitor AZD2281 alone and in combination with platinum drugs. Proc Natl Acad Sci U S A 2008; 105:17079-84.

60 Farmer H, McCabe N, Lord CJ, Tutt ANJ, Johnson DA, Richardson TB, Santarosa M, Dillon KJ, Hickson I, Knights C, Martin NMB, Jackson SP, Smith GCM, Ashworth A. Targeting the DNA repair defect in BRCA mutant cells as a therapeutic strategy. Nature 2005;434:917-21.

61 Bryant HE, Schultz N, Thomas HD, Parker KM, Flower D, Lopez E, Kyle S, Meuth M, Curtin NJ, Helleday T. Specific killing of BRCA2-deficient tumours with inhibitors of poly(ADP-ribose) polymerase. Nature 2005;434:913-7.

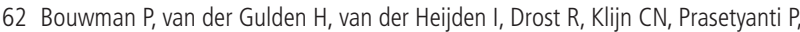
Pieterse M, Wientjens E, Seibler J, Hogervorst FBL, Jonkers J. A high-throughput functional complementation assay for classification of BRCA1 missense variants. Cancer Discov 2013;3:1142-55.

63 Drost R, Bouwman P, Rottenberg S, Boon U, Schut E, Klarenbeek S, Klijn C, van der Heijden I, van der Gulden H, Wientjens E, Pieterse M, Catteau A, Green P, Solomon $E$, Morris JR, Jonkers J. Brca1 ring function is essential for tumor suppression but dispensable for therapy resistance. Cancer Cell 2011;20:797-809.

64 Lheureux S, Lai Z, Dougherty BA, Runswick S, Hodgson DR, Timms KM, Lanchbury JS, Kaye S, Gourley C, Bowtell D, Kohn EC, Scott C, Matulonis U, Panzarella T, Karakasis K, Burnier JV, Gilks CB, O'Connor MJ, Robertson JD, Ledermann J, Barrett JC, Ho TW, Oza AM. Long-Term responders on olaparib maintenance in high-grade serous ovarian cancer: clinical and molecular characterization. Clin Cancer Res 2017;23:4086-94.

65 Mirza MR, Monk BJ, Herrstedt J, Oza AM, Mahner S, Redondo A, Fabbro M, Ledermann JA, Lorusso D, Vergote I, Ben-Baruch NE, Marth C, Mądry R, Christensen RD, Berek JS, Dørum A, Tinker AV, du Bois A, González-Martín A, Follana P, Benigno B, Rosenberg P, Gilbert L, Rimel BJ, Buscema J, Balser JP, Agarwal S, Matulonis UA, ENGOT-OV16/NOVA Investigators. Niraparib maintenance therapy in platinum-sensitive, recurrent ovarian cancer. $N$ Engl J Med 2016;375:2154-64.

66 Coleman RL, Oza AM, Lorusso D, Aghajanian C, Oaknin A, Dean A, Colombo N, Weberpals JI, Clamp A, Scambia G, Leary A, Holloway RW, Gancedo MA, Fong PC, Goh JC, O'Malley DM, Armstrong DK, Garcia-Donas J, Swisher EM, Floquet A, Konecny GE, McNeish IA, Scott CL, Cameron T, Maloney L, Isaacson J, Goble S, Grace C, Harding TC, Raponi M, Sun J, Lin KK, Giordano H, Ledermann JA, Buck M, Dean A, Friedlander ML, Goh JC, Harnett P, Kichenadasse G, Scott CL, Denys H, Dirix L, Vergote I, Elit L, Ghatage P, Oza AM, Plante M, Provencher D, Weberpals JI, Welch S, Floquet A, Gladieff L, Joly F, Leary A, Lortholary A, Lotz J, Medioni J, Tredan O, You B, El-Balat A, Hänle C, Krabisch P, Neunhöffer T, Pölcher M, Wimberger P, Amit A, Kovel S, Leviov M, Safra T, Shapira-Frommer R, Stemmer S, Bologna A, Colombo N, Lorusso D, Pignata S, Sabbatini RF, Scambia G, Tamberi S, Zamagni C, Fong PC, O'Donnell A, Gancedo MA, Herraez AC, Garcia-Donas J, Guerra EM, Oaknin A, Palacio I, Romero I, Sanchez A, Banerjee SN, Clamp A, Drew Y, Gabra HG, Jackson D, Ledermann JA, McNeish IA, Parkinson C, Powell M, Aghajanian C, Armstrong DK, Birrer MJ, Buss MK, Chambers SK, Chen L-m, Coleman RL, Holloway RW, Konecny GE, Ma L, Morgan MA, Morris RT, Mutch DG, O'Malley DM, Slomovitz BM, Swisher EM, Vanderkwaak T, Vulfovich M, investigators A. Rucaparib maintenance treatment for recurrent ovarian carcinoma after response to platinum therapy (ARIEL3): a randomised, double-blind, placebocontrolled, phase 3 trial. Lancet 2017;390:1949-61.

67 Cong L, Ran FA, Cox D, Lin S, Barretto R, Habib N, Hsu PD, Wu X, Jiang W, Marraffini LA, Zhang F. Multiplex genome engineering using CRISPR/Cas systems. Science 2013;339:819-23.

68 Wang H, Yang H, Shivalila CS, Dawlaty MM, Cheng AW, Zhang F, Jaenisch R. One-Step generation of mice carrying mutations in multiple genes by CRISPR/Cas-mediated genome engineering. Cell 2013;153:910-8.

69 Landrum MJ, Lee JM, Benson M, Brown G, Chao C, Chitipiralla S, Gu B, Hart J, Hoffman D, Hoover J, Jang W, Katz K, Ovetsky M, Riley G, Sethi A, Tully R, VillamarinSalomon R, Rubinstein W, Maglott DR. ClinVar: public archive of interpretations of clinically relevant variants. Nucleic Acids Res 2016;44:D862-8.

70 Morris JR, Pangon L, Boutell C, Katagiri T, Keep NH, Solomon E. Genetic analysis of BRCA1 ubiquitin ligase activity and its relationship to breast cancer susceptibility. Hum Mol Genet 2006;15:599-606.

71 Starita LM, Young DL, Islam M, Kitzman JO, Gullingsrud J, Hause RJ, Fowler DM, Parvin JD, Shendure J, Fields $S$. Massively parallel functional analysis of BRCA1 ring domain variants. Genetics 2015;200:413-22.

72 Petitalot A, Dardillac E, Jacquet E, Nhiri N, Guirouilh-Barbat J, Julien P, Bouazzaoui I, Bonte D, Feunteun J, Schnell JA, Lafitte P, Aude J-C, Noguès C, Rouleau E, Lidereau R, Lopez BS, Zinn-Justin S, Caputo SM, UNICANCER Genetic Group BRCA network. Combining homologous recombination and Phosphopeptide-binding data to predict the impact of BRCA1 BRCT variants on cancer risk. Mol Cancer Res 2019;17:54-69.

73 Anantha RW, Simhadri S, Foo TK, Miao S, Liu J, Shen Z, Ganesan S, Xia B. Functional and mutational landscapes of BRCA1 for homology-directed repair and therapy resistance. Elife 2017;6:e21350.

74 Guidugli L, Shimelis H, Masica DL, Pankratz VS, Lipton GB, Singh N, Hu C, Monteiro ANA, Lindor NM, Goldgar DE, Karchin R, Iversen ES, Couch FJ. Assessment of the clinical relevance of BRCA2 missense variants by functional and computational approaches. Am J Hum Genet 2018;102:233-48.

75 Mesman RLS, Calléja FMGR, Hendriks G, Morolli B, Misovic B, Devilee P, van Asperen $\mathrm{CJ}$, Vrieling $\mathrm{H}$, Vreeswijk MPG. The functional impact of variants of uncertain significance in BRCA2. Genet Med 2019;21:293-302. 